\title{
Metodologi Tafsir Darul Islam Fillah : Studi Atas Ayat-Ayat Kerasulan
}

\author{
Ismi Lutfi Rijalul Fikri Syukur ${ }^{1}$, Badruzzaman M Yunus² \\ 1,2Pascasarjana Ilmu Al-Qur'an dan Tafsir UIN Sunan Gunung Djati Bandung \\ Email: lutfielfikri88@gmail.com¹, badruzzamanmyunus@uinsgd.ac.id²
}

\begin{abstract}
In the history of Islam, the Muslims since the time of the Holy Prophet. until today it is agreed to hold the view that prophethood and / or apostolate ended with the presence of the Prophet Muhammad. Unlike the case with Darul Islam Fillah, where they are of the view that prophethood is not over, neither is the apostolate. This is based on the Qur'an not found the sentence khatam ar-rasul which states that the apostle has ended, while what is found is only the sentence khatam an-nabiyyin that in the Qur'an the sentence is only found in one verse, namely QS. al-Ahzab [33]: 40. While the word khatam itself is interpreted by many meanings, namely: stamp, ring, perfection and cover. The interpretation of khatam by Darul Islam Fillah is certainly not in line with the doctrine of khatam an-nabiyyin which is deduced from the verse and the hadiths which reach muthatage, both lafdzi and ma'nawi. Moreover, the experts of qira'ah who are members of qira'ah sab'ah are mut worried, the majority of them read it with kasrah (khatim an-nabiyyin), which means the closing of the prophets. So that the interpretation of the sentence khatam an-nabiyyin must also be adjusted to the qira'ah khatim an-nabiyyin, which does not leave speculations on the meaning of the khatam with a stamp, ring, perfection, and so forth. Interpreting and analyzing various problems from the Qur'an is a very difficult scientific process. Therefore, a commentator must have the completeness of knowledge, standards and criteria, and parameters to ensure the correctness of interpretation, and the correct methodology to measure the accuracy of the interpretation in accordance with the aims and objectives of the Qur'an.
\end{abstract}

Keywords: Darul Islam Fillah, Interpretation, Methodology

\begin{abstract}
ABSTRAK
Dalam sejarah Islam, kaum muslimin sejak masa Nabi saw. hingga dewasa ini sepakat berpandangan bahwa kenabian dan atau kerasulan berakhir dengan kehadiran Nabi Muhammad saw. Berbeda halnya dengan Darul Islam Fillah, di mana mereka berpandangan bahwa kenabian belum berakhir, begitupun dengan kerasulan. Hal tersebut berdasar di dalam al-Qur'an tidak ditemukan kalimat khatam ar-rasul yang menyatakan bahwa rasul telah berakhir, sementara yang ditemukan hanyalah kalimat khatam annabiyyin yang dalam al-Qur'an kalimat tersebut hanya terdapat dalam satu ayat yaitu QS. al-Ahzab [33] 40. Sedangkan kata khatam sendiri oleh mereka dimaknai dengan banyak arti, yaitu: stempel, cincin, penyempurna dan penutup. Pemaknaan khatam oleh Darul Islam Fillah tersebut tentu saja tidak sejalan dengan doktrin khatam an-nabiyyin yang disimpulkan dari ayat tersebut dan hadits-hadits yang derajatnya mencapai mutawatir, baik lafdzi maupun ma'nawi. Apalagi para pakar qira'ah yang tergabung dalam qira'ah sab'ah yang mutawatir, mayoritas mereka membacanya dengan kasrah (khatim annabiyyin), yang berarti penutup para nabi. Sehingga penafsiran kalimat khatam an-nabiyyin harus pula disesuaikan dengan qira'ah khatim an-nabiyyin, yang tidak menyisakan spekulasi pemaknaan khatam itu dengan stempel, cincin, penyempurna, dan lain sebagainya. Melakukan penafsiran dan menganalisa berbagai permasalahan dari al-Qur'an memang merupakan proses ilmiah yang sangat berat. Oleh karena itu, seorang mufassir harus memiliki kelengkapan ilmu, standar dan kriteria, serta parameter guna menjamin kebenaran penafsiran, dan metodologi yang benar guna mengukur tingkat akurasi penafsiran tersebut sesuai dengan maksud dan tujuan al-Qur'an.
\end{abstract}

Kata kunci: Darul Islam Fillah, Metodologi, Tafsir

\footnotetext{
* Copyright (c) 2020 Ismi Lutfi Rijalul Fikri Syukur dan Badruzzaman M Yunus

This work is licensed under a Creative Commons Attribution-ShareAlike 4.0 International License.
}

Diterima: 2 April 2020; Direvisi: 25 April 2020; Disetujui: 27 April 2020 


\section{PENDAHULUAN}

Darul Islam Fillah (DI-Fillah) (Zada, 2017) pimpinan Sensen Komara yang berbasis di Garut, telah mengklaim menghidupkan kembali Negara Islam Indonesia yang pertama kali diproklamirkan oleh S.M. Kartosoewirjo. Mereka berpandangan, bahwa kewajiban mendirikan Negara Islam pada saat ini merupakan hal yang amat mendesak untuk dilakukan, karena Indonesia sudah berada diambang kehancuran, "terapung tak hanyut, tenggelam tak basah", tandas mereka. Ketidaksediaan untuk mendirikan Negara Islam berarti pembangkangan terhadap syari'at Islam.

Dalam melancarkan misinya untuk mendirikan Negara Islam Indonesia, kelompok ini mengajukan pelbagai dalil dari al-Qur'an dan Sunnah, melakukan penafsiran terhadap al-Qur'an_salah satunya_atas ayat-ayat kerasulan dengan merepresentasikan penafsirannya pada kepentingan dan ideologi yang sedang diperjuangkan yaitu pendirian Negara Islam Indonesia. Penafsiran atas ayat-ayat kerasulan dilakukan sebagai usaha DI-Fillah untuk mencapai kekuasaan melalui konversi dari RI (Republik Indonesia) ke NII (Negara Islam Indonesia) dengan seorang rasul sebagai pemegang kekuasannya.

Patut disadari, bahwa setiap manusia kapan dan di mana pun berhak untuk mencari penjelasan dalam al-Qur'an (Abidin \& Khairudin, 2017). Sebab, untuk merekalah al-Qur'an diturunkan. Namun perlu digarisbawahi, hal itu tidak berarti bahwa setiap manusia, siapa saja, berhak untuk menafsirkannya. Karena menafsirkan al-Qur'an merupakan salah satu aktivitas intelektual yang terikat dengan berbagai macam disiplin keilmuan, As-Suyuthi menyebutkan 15 disiplin ilmu terkait yang harus dikuasai dalam aktivitas penafsiran al-Qur'an. Seperangkat disiplin keilmuan tersebut diperlukan bagi mufasir yang hendak tampil menafsirkan al-Qur'an secara keseluruhan, guna menuntun mufasir pada suatu jalan untuk menemukan penafsiran secara akurat dan memadai. Sedangkan bagi mereka yang tidak memenuhi syarat-syarat tersebut, tidak dibenarkan untuk menafsirkan al-Qur'an.

Selain itu, mufasir juga tidak boleh mempunyai kepentingan yang lebih dahulu ada dimana ia ingin mencari peneguhan dari al-Qur'an, serta mempunyai pra-konsepsi dimana ia ingin mencari penguat bagi pandangannya dari al-Qur'an. Jika ia melakukan itu, maka ia akan mencondongkan istilah-istilah dan ayatayat al-Qur'an untuk melayani kepentingannya serta menguatkan pemikirannya (Al-Khalidi, 2008).

Dalam melakukan penafsiran, seorang mufasir harus memiliki metodologi yang benar atau prosedur tetap yang disepakati agar hasil yang dicapai dari penafsiran akurat dan memadai, sebagai upaya memelihara al-Qur'an dari pemaknaan yang keliru dan menyimpang, serta memelihara agama Islam dari penyimpangan pemahaman mereka yang berlebihan dan melampaui batas, pemalsuan ahli kebathilan dan penafsiran orang-orang yang tidak memiliki metodologi yang benar dalam mengambil sebuah konsep yang dikehendaki dan ditunjukan oleh al-Quran.

\section{METODE PENELITIAN}

Metodologi berasal dari kata metode dan logos. Kata metode artinya "cara atau jalan" yang berarti cara yang tepat untuk melakukan sesuatu; dan logos artinya ilmu atau pengetahuan. Dengan demikian, metodologi adalah ilmu tentang metode, yaitu cara-cara yang teratur dan terpikir baik-baik dalam melakukan sesuatu untuk mencapai tujuan yang hendak dicapai (Baidan \& Aziz, 2016).

Sedangkan tafsir adalah suatu usaha penalaran atau ijtihad manusia untuk menyingkap kandungan ayat-ayat al-Qur'an yang tidak atau belum jelas maksudnya menjadi jelas, yang samar menjadi terang, sehingga menghasilkan pemahaman.

Dengan demikian, metodologi tafsir adalah ilmu tentang penafsiran al-Qur'an, yaitu cara-cara atau suatu perangkat dan tata kerja yang digunakan untuk menyingkap firman Allah swt. dalam al-Qur'an, dengan memperhatikan rumusan dan kaidah-kaidah penafsiran sebagai ukuran jauh dekatnya penafsiran 
dengan apa yang dikehendaki Allah swt. Sehingga al-Qur'an yang salah satu fungsi esensialnya sebagai kitab hidayah dapat dipahami, dihayati, dan diamalkan dalam kehidupan sebagaimana mestinya, demi tercapainya kebahagiaan hidup di dunia dan akhirat.

Dalam pada itu, penelitian ini hendak membahas mengenai metode, sumber atau pendekatan, dan corak tafsir yang digunakan DI-Fillah atas ayat-ayat kerasulan. Penelitian ini diharapkan dapat bermanfaat untuk memberikan informasi yang komprehensif tentang metodologi tafsir DI-Fillah, lebih jauh lagi diharapkan dapat mencounter penafsiran lain yang tidak mempunyai metodologi yang kukuh dalam melakukan penafsiran terhadap al-Qur'an serta dengan pendekatan kualitatif dalam penjelasan setiap hasil yang penuliskan yaitu dengan mendeskripsikan data - data yang di dapatkan (Sugiyono, 2013).

\section{HASIL DAN PEMBAHASAN}

\section{Darul Islam Fillah}

Sejak 17 Februari 1948, umat Islam bangsa Indonesia di bawah pimpinan SM. Kartosoewiryo telah mengumumkan dan melancarkan perang suci, jihad fi sabilillah yaitu jihad dalam arti qital (perang) dalam mengusir Belanda penjajah dari permukaan bumi Indonesia dengan disertai pelbagai ketentuan dan peraturan yang formil dan dengan segala saluran yang ril.

Hal tersebut berjalan terus sampai dikeluarkannya perintah penghentian tembak-menembak oleh SM. Kartosoewiryo pada tanggal 24 April 1962, yang beberapa saat sebelumnya didahului dengan perintah jihad Fillah (jihad dengan meninggalkan perjuangan bersenjata) dan perintah penyelamatan dhahir-batin mujahidin dan kaum muslimin, sehingga mulai hari itu berubahlah bentuk jihad dari jihad $f i$ sabilillah menjadi jihad fillah. Perintah 24 April 1962 itu telah disebarluaskan oleh Kodam VI Siliwangi pada tanggal 6 Juni 1962 dengan disertakan atasnya perintah mendaftarkan diri ke pos-pos TNI terdekat.

Pasca turun perintah dari Imam tertinggi NII Kartosoewiryo agar para pengikutnya kembali ke pangkuan ibu pertiwi dan setia kepada Pancasila dan UUD-1945 demi penyelamatan mujahidin dan kaum muslimin secara dhahir dan bathin, sebagian pengikut NII kemudian ada yang taat terhadap perintah Kartosoewiryo tersebut yang kemudian membentuk DI-Fillah dengan meninggalkan perjuangan bersenjata, yaitu gerakan NII non struktural yang dijalankan secara kolektif oleh Agus Abdullah, Kadar shalihat, dan Djadja Sudjadi. Dan sebagian pengikut yang lain membentuk DI-Fisabilillah yang menafikan perintah jihad fillah dan tetap mengobarkan perang, yakni NII struktural yang didominasi oleh para mantan komandan dan resimen militer NII.

DI-Fillah sebagai kelompok yang melaksanakan isi maklumat Kartosoewirjo (Ruhana, 2011), dibawah tanggung jawab Djadja Sudjadi, yang merupakan mantan bendahara umum Kartosoewirjo dan salah satu orang terdekatnya kemudian mengikuti aturan Negara Republik Indonesia sesuai dengan perintah imam mereka, dengan tidak menghapuskan ideologi NII. Ketika itu, kebanyakan kegiatankegiatannya hanya terpusat pada gerakan dakwah dan pendalaman ajaran Islam.

Hal serupa juga terjadi ketika DI-Fillah dibawah pimpinan Bakar Misbah di mana ia berikrar di Kodam VI Siliwangi pada tahun 1985 yang antara lain isinya adalah: "Saya akan ta'at kepada pemerintahan Republik Indonesia dan saya tidak akan mau diajak dan ta'at kepada siapapun yang mengajak-ngajak untuk merusak agama, bangsa, dan negara" (Ruhana, 2011).

Setelah Bakar Misbah Wafat, berdasar hasil munajat mujtahidin, Sensen Komara diangkat menjadi pemimpin DI-Fillah pada 7 November 1993. Sensen Komara tidak lain merupakan anak dari Bakar Misbah, Bupati NII Sumedang ketika pertama kali dicetuskan. Sensen Komara lahir pada tanggal 12 Oktober 1964 di Kampung Babakan Cipari, Desa Sukarasa, Kecamatan Pangatikan, Kabupaten Garut, dan sekarang menetap di Kampung Bayubud, Desa Sindangpalay, Kecamatan Karangpawitan. Wilayah garut 
memang merupakan basis pergerakan Darul Islam dari dulu hingga sekarang dengan munculnya DIFillah.

Sensen, pria lulusan Universitas Islam Negeri Sunan Gunung Djati Bandung jurusan Perbandingan Agama lulusan 1990 itu, kemudian mengklaim bahwa dirinya menghidupkan kembali Negara Islam Indonesia yang pernah diproklamasikan Kartosoewiryo pada 7 Agustus 1949. Hal itu ia lakukan karena menurutnya telah terjadi kembali penodaan terhadap UUD 1945 pada zaman reformasi, yang ia sebut dengan historicht onrecht (sejarah penghianatan), Negara Kesatuan tahun 1950 lahir kembali dengan diadakannya Pemilu pada tanggal 7 Juni 1999. Maka Pemerintah RI dan MPR yang dihasilkan oleh Pemilu pada tanggal 29 Mei 1997 telah melanggar dan mengkhianati pasal 7 dan 8 UUD 1945.

Dengan dikhianatinya UUD 1945, maka struktur ketatanegaraan RI dan biodata negara RI dirubah menjadi struktur ketatanegaraan NKRI. Dengan berubahnya struktur ketatanegaraan Negara Rebuplik Indonesia dan berubahnya UUD-45 oleh MPR yang tidak sah, jelaslah sudah menurutnya bahwa Negara Rebuplik Indonesia sudah tidak ada. Yang ada sekarang ini di Indonesia adalah negara baru "NKRI" yaitu negara hasil pengkhianatan terhadap RI-45 dan UUD-45. Hingga penanggung jawab DI-Fillah, Sensen memerintahkan kepada seluruh anggotanya supaya tidak mengikuti Pemilu yang diadakan pada tanggal 7 Juni 1999 dan merubah RI menjadi NII dengan jalan konversi.

Dengan anggapan bahwa RI-45 telah mati sejak berdirinya negara baru yaitu Negara RIS-1949, NKRI-1950 dan NKRI-Reformasi di Indonesia, ketiga negara itu tidak memiliki bendera. Hingga pada 18 Januari 2008, Sensen dengan disaksikan oleh warga DI-Fillah mengibarkan bendera Madinah Indonesia (bendera merah putih berlambangkan bulan bintang).

Pada pertengahan tahun 2007, Sensen mengaku sebagai nabi dan rasul yang dijanjikan akan turun diakhir zaman (Isa al-Masih al-Mau'ud) dan merubah syahadat dengan ucapan: "Asyhadu an laa ilaha illallah wa asyhadu anna Drs. Sensen Komara bin Bakar Misbah bin KH. Abdul Mughni Rasulullah", serta merubah arah shalat (kiblat) dengan menghadap ke arah timur. Pengikut DI-Fillah yang awalnya puluhan ribu, berkurang drastis menjadi 2009 berdasar pendataan tahun 2019, yang tersebar di beberapa kecamatan dengan pengikut terbanyak terpusat di wilayah Caringin, Garut bagian selatan. Jumlah tersebut termasuk yang masih dalam kandungan dan yang sudah meninggal (Komara, 2019).

\section{Tafsir dan Penafsiran Menurut Darul Islam Fillah}

Sebelum menganalisa metodologi tafsir DI-Fillah atas ayat-ayat kerasulan, perlu kiranya penulis kemukakan terlebih dahulu mengenai pengertian tafsir dan penafsiran dalam pandangan DI-Fillah. Sebab, pandangan ini memiliki pengaruh besar atas penetapan metodologi tafsir mereka.

Menurut Sensen, tafsir berasal dari kata sir yang berarti rahasia. Di mana hal ini mengisyaratkan hanya sedikit saja sahabat yang diberitahu oleh Nabi saw. mengenai penafsiran suatu ayat dalam al-Qur'an dengan cara bisik-bisik, atau bahkan tidak ada yang diberitahu seorangpun mengenai penafsirannya (Komara, 2019).

Atau terambil dari kata sar atau surur yang berarti bahagia atau tertawa. Maksudnya, Nabi saw. mengucapkan makna suatu ayat dari al-Qur'an dalam arti sesungguhnya atau bukan, majazi atau hakiki. Karena bisa jadi menurut Sensen, Nabi saw. mengucapkannya dalam keadaan bercanda (Komara, 2019).

Atau bisa juga terambil dari kata sarir yang berarti ranjang. Yaitu suatu hiasan yang indah, yang mengandung makna bahwa tafsir itu adalah sebuah seni atau keindahan. Jadi, tafsir adalah cara bagaimana memahami isi hati Nabi saw (Komara, 2019). 
Dengan pengertian seperti ini, Sensen telah mendefinisikan tafsir dengan makna kontekstual dengan mengesampingkan kemapanan bahasa, dengan mencari padanan kata yang mendekati, baik dalam bahasa arab, indonesia, inggris, ataupun sunda.

Dalam pandangan DI-Fillah, penafsiran yang ada hingga dewasa ini tidak pernah selesai, dengan banyaknya perbedaan dalam penafsiran_bahkan_terhadap satu ayat al-Qur'an, dan banyaknya kitab tafsir yang bahkan saling bertentangan satu sama lain, sehingga hal tersebut hanya akan membingungkan umat. Penafsiran terhadap al-Qur'an menurut mereka, hanya akan selesai dan benar bila penafsiran tersebut bersumber dari Allah swt. lewat wahyu, sumber yang sama dengan al-Qur'an. Sebagaimana pengakuan Sensen, bahwa ia telah menerima wahyu dari Allah swt. dengan media yang sama seperti pewahyuan terhadap Nabi Muhammad saw. Lanjut mereka, sulit menemukan kebenaran sebuah penafsiran karena ketidaksezamanan dengan Nabi saw., dan Nabi saw. pun telah meninggal, begitu pula dengan para sahabat. Sedangkan, tidak ditemukan penafsiran al-Qur'an secara utuh dari mereka (Rahayu, 2019).

Dengan demikian, DI-Fillah mempunyai kecenderungan untuk menyeragamkan penafsiran terhadap al-Qur'an pada satu tafsiran saja. Mereka melakukan penafsiran secara otoriter, yaitu dengan mengunci dan mengurung kehendak teks ke dalam sebuah penetapan makna tertentu, dan kemudian menyajikannya sebagai sesuatu yang pasti ( $q a t h^{\prime} i$ ), absolut, dan bersifat determinan, karena berasal dari Allah swt. Dengan hal ini, secara tidak langsung mereka mengklaim sebagai juru bicara teks yang paling otoritatif dan mumpuni dalam melakukan penafsiran terhadap al-Qur'an.

DI-Fillah mengakui keabsahan wahyu sebagai kalam Ilahi, dan al-Qur'an bersumber dari-Nya. Maka untuk mencapai pada pemahaman teks yang benar, penafsiran harus juga bersumber dari-Nya. Di kalangan para sarjana tafsir sendiri, hal ini bukan sesuatu yang asing dengan adanya sebagian orang yang mengklaim bahwa Allah swt. mengendalikan pikiran mereka. Jalur alternatif untuk menafsirkan al-Qur'an lewat inspirasi-intuisi (isyari) sebagai sumber atau pendekatan mufasir terhadap al-Qur'an, dan mencapai popularitasnya dalam pemikiran mistis tradisionalis islamis. Hanya saja, DI-Fillah mengganggap hal itu sebagai satu-satunya jalan menyatukan penafsiran dalam satu kebenaran.

Hal ini tentu saja akan berdampak pada keringnya diskursus keislaman, serta menghentikan seluruh upaya (ijtihad) para sarjana tafsir dalam melakukan penelitian terhadap al-Qur'an. DI-Fillah mengembalikan semuanya seperti pada masa Rasul saw., di mana pada saat itu hanya Rasul saw. yang mempunyai otoritas untuk menafsirkan al-Qur'an.

\section{Metodologi Tafsir Darul Islam Fillah atas Ayat-Ayat Kerasulan}

\section{Metode Tafsir}

Dalam melakukan penafsiran, DI-Fillah tidaklah menjelaskan seluruh aspek yang terkandung dalam al-Qur'an secara tartib mushhafi (susunan mushaf) atau mengungkapkan seluruh pengertian yang ditujunya (metode tahlili). Tapi, mereka menafsirkan al-Qur'an secara tematik (maudhu'i) dengan memilih tema-tema yang menjadi legitimasi pendirian Negara Islam Indonesia, atau sebagai pendukung bagi kebijakan-kebijakan DI-Fillah, serta pembelaan terhadap ideologi mereka.

Oleh karena itu tidak ditemukan karya utuh mengenai penafsiran DI-Fillah, yang ada hanyalah penafsiran dengan tema-tema tertentu yang penulis temukan dalam pleidoi atau nota pembelaan Negara Islam Indonesia di pengadilan Negeri Garut pada tahun 2008 Dengan judul "Kacamata Sunnah (Aplikasi Sunnah dalam Menyelamatkan Negara Indonesia Melalui Konversi)" yang ditulis oleh Deden Rahayu Setiana dan Endi Rustandi. Pleidoi 2009 Dengan judul "Argumentasia (A New World Religion and The Man From The East)" yang ditulis oleh Daud bin KH. Amin, Wowo Wahyudin, Wawan Setiawan, dan Abdul Rasyid. Pleidoi 2010 Dengan judul "Argumentasia (Mengapa Aku Percaya?)" yang ditulis oleh Wawan Setiawan, Wowo Wahyudin, dan Abdul Rasyid. Kesemua pleidoi tersebut memuat beberapa 
permasalahan yang sama, yaitu: sunnah Nabi Muhammad di tanah Arab, perjuangan SM. Kartosuwiryo di Indonesia, tentang hijrah (konversi dari RI menjadi NII), kerasulan, syahadat, perubahan kiblat, dan imamah.

Secara semantik, at-tafsir al-maudhu'i berarti tafsir tematis. Metode ini mempunyai tiga bentuk: Pertama, tafsir yang membahas istilah-istilah yang terdapat dalam al-Qur'an, dengan memilih lafad yang banyak terulang dalam al-Qur'an, menghimpunya, dan kemudian memberikan penjelasan dan kesimpulan, seperti: jihad, adil, amanah, riba, zakat, dan lain sebagainya. Kedua, tafsir yang membahas tema-tema yang terdapat dalam al-Qur'an, dengan menghimpun dan menyusun ayat-ayat al-Qur'an yang memiliki kesamaan arah dan tema, kemudian memberikan penjelasan dan kesimpulan di bawah satu bahasan tema tertentu, seperti: kisah-kisah umat terdahulu dalam al-Qur'an, kepribadian seorang muslim dalam al-Qur'an, nifaq dan perbuatan-perbuatan tercela orang-orang munafik dalam al-Qur'an, dan lain sebagainya. Ketiga, tafsir yang membahas surat-surat dalam al-Qur'an, dengan membahas satu surat dalam al-Qur'an secara menyeluruh, memperkenalkan dan menjelaskan maksud-maksud umum dan khususnya secara garis besar, dengan cara menghubungkan ayat per-ayat, dan atau antara satu pokok masalah dengan pokok masalah lain dapat dilihat pada Muslim (1997) dan bandingkan dengan Shihab (2013).

Dengan melihat tiga bentuk tafsir maudhu'i tersebut, maka metode tafsir maudhu'i yang digunakan DI-Fillah mengenai ayat-ayat kerasulan adalah metode tafsir yang membahas tema-tema yang terdapat dalam al-Qur'an, dengan menghimpun dan menyusun ayat-ayat al-Qur'an yang memiliki kesamaan arah dan tema, kemudian memberikan penjelasan dan kesimpulan di bawah satu bahasan tema tertentu. Dengan menentukan tema kerasulan, kemudian memilih ayat-ayat yang menurut mereka menunjukkan adanya rasul setelah kerasulan Nabi Muhammad saw.

\section{Sumber atau Pendekatan Tafsir}

Sumber atau pendekatan tafsir yang digunakan DI-Fillah pada penafsiran mereka terhadap ayatayat kerasulan adalah dengan menggunakan pendekatan bi ar-rayi pada beberapa penafsiran, dan juga menggunakan pendekatan isyari pada beberapa penafsiran yang lain.

Pendekatan dengan menggunakan tafsir bi ar-rayi misalnya terlihat ketika DI-Fillah berargumen akan adanya rasul setelah Nabi Muhammad saw. dengan menafsirkan QS. Ad-Dukhan [44]: 5

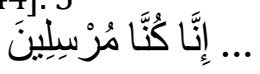

“... Sesungguhnya Kami adalah yang mengutus rasul-rasul”.

Menurut DI-Fillah, kalimat mursilin dalam ayat tersebut adalah kata sifat, yang berarti "yang selalu mengutus rasul-rasul". Karena mursilin adalah sifat Tuhan, maka Tuhan tidak akan pernah berhenti mengutus para utusan-Nya (Setiawan, 2010).

Penggunaan tafsir bi ar-ra'yi juga terlihat ketika DI-Fillah menafsirkan QS. Al-Mu'minun [23]: 43-44

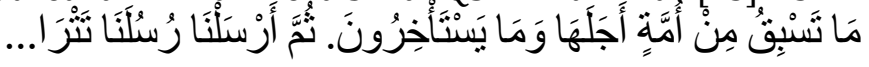

"Tidak (dapat) sesuatu umat pun mendahului ajalnya, dan tidak (dapat pula) mereka terlambat (dari ajalnya itu). Kemudian Kami utus (kepada umat-umat itu) rasul-rasul Kami berturut-turut..."

Ayat di atas menggunakan "min ummatin" yang menurut DI-Fillah, kalimat itu menjadikannya bersifat umum, sehingga ketentuan tersebut berlaku untuk semua masyarakat manusia. Ayat di atas lanjutnya, senisbat dengan firman Allah QS. Yunus [10]: 49

“... Tiap-tiap umat mempunyai ajal...”

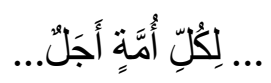


Ketika suatu umat atau bangsa akan mengalami kehancuran, maka Allah akan mengutus utusanNya, maka ayat di atas dilanjutkan dengan:

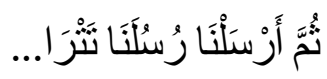

"Kemudian Kami utus (kepada umat-umat itu) rasul-rasul Kami berturut-turut..."

Dalam ayat tersebut diawali dengan kalimat " untuk memperbaiki kehancuran, maka Allah akan mengutus utusan-Nya secara berturut-turut.

Sedangkan penggunaan pendekatan tafsir isyari bisa dilihat dari penafsiran DI-Fillah terhadap QS. al-Ahzab [33]: 40

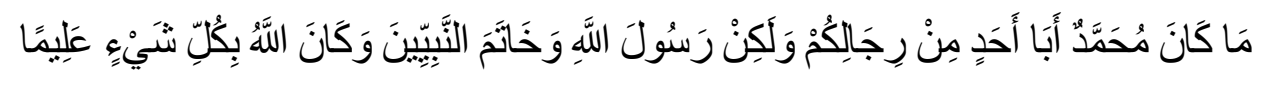

Artinya: "Muhammad itu sekali-kali bukanlah bapak dari seorang laki-laki di antara kamu, tetapi dia adalah Rasulullah dan penutup nabi-nabi. Dan adalah Allah Maha Mengetahui segala sesuatu."

DI-Fillah mengatakan, bahwa di dalam al-Qur'an tidak ditemukan kalimat khatam ar-rasul yang menyatakan bahwa Rasul telah berakhir, sementara yang ditemukan hanyalah kalimat khatam annabiyyin yang dalam al-Qur'an kata tersebut hanya terdapat dalam satu ayat yaitu surat al-Ahzab [33]: 40. Sedangkan kalimat khatamun sendiri mempunyai banyak arti, yaitu: stempel, cincin, penyempurna dan penutup (Setiawan, 2010).

Kalimat khatamun nabiyyin menurut DI-Fillah dalam surat al-Ahzab tersebut dalam pengertian sastra berarti "selesai", ayat ini turun berkaitan dengan wafatnya Nabi Muhammad saw. Ketika Nabi Muhammad saw. dikuburkan, apa yang diucapkan oleh para sahabat adalah kalimat khatam an-nabiyyin, dalam arti bahwa kenabian Muhammad saw. telah selesai, dan mereka tidak akan melihatnya lagi, atau melihat nabi yang seperti Nabi Muhammad saw (Komara, 2019).

Kata khatam, dimaknai dengan arti "sempurna". Ayat tersebut berkaitan dengan turunya perintah kepada Nabi Muhammad saw. untuk menikahi mantan istri anak angkatnya Zaid bin Haritsah, yaitu Zainab binti Jahsy. Menurut tradisi Arab, menikahi istri anak angkat sama dengan menikahi istri anak sendiri, dan hal tersebut sangat tabu. Namun ternyata Nabi Muhammad saw. mampu melaksanakan apa yang diperintahkan Allah swt. dengan sempurna, hingga berhasil membatalkan keyakinan bangsa arab jahiliyah seputar hukum menikahi mantan istri anak angkat (Rahayu, 2019).

DI-Fillah meyakini bahwa pintu kerasulan belum tertutup, begitu juga dengan pintu kenabian. Menurut mereka, bahwa setiap rasul pasti nabi, tapi nabi belum tentu rasul. Mereka memaknai nabi dengan orang yang berhasil atau membuahkan, yang berhasil bagaikan pohon yang berbuah. Nabi juga oleh mereka diartikan baitun yang berarti rumah, lebih jauh dari rumah lanjut mereka itu negara, biladi atau baldatun (Komara, 2019).

Sedangkan rasul menurut DI-Fillah adalah utusan pembawa amanat atau perintah Allah, pelaksana dan realisator kehendak, kekuasaan dan lain-lain sifat afaliyah-Nya yang berhubungan dengan manusia dan alam lainnya di permukaan bumi, serta menjadi contoh atau teladan bagi ummat pengikutnya dalam menyembah bakti kepada-Nya. Tegas mereka, ia adalah pemimpin pembawa ideologi atau agama, sehingga setiap pembawa ideologi bisa disebut rasul bagi Tuhan pemberi wahyu atau inspirasi agama atau ideologi yang bersangkutan (Arsip Darul Islam Fillah, 1975).

Bahkan, menurut DI-Fillah rasul itu bukan hanya sekedar orang yang diberikan wahyu dan diperintahkan untuk menyampaikan kepada umatnya, sampai pemimpin ditingkat RT (rukun tetangga) dan rumah tangga pun bisa disebut sebagai seorang rasul. Menurut mereka, rasul itu ada rasul kecil, menengah, dan besar. Dan rasul besar ini adalah seseorang yang memimpin dunia dan harus sempurna, harus ahli dalam segala hal, harus bisa membuat segala (Komara, 2019). 


\section{Corak Tafsir}

Sekitar abad ketiga hijriah, ketika berakhirnya masa salaf, di mana peradaban Islam semakin berkembang, disertai juga periode tersebut dengan lahirnya berbagai aliran di kalangan umat Islam. Masing-masing aliran itu berusaha meyakinkan pengikutnya dengan memberikan penjelasan dari ayatayat al-Qur'an, yang kemudian ditafsirkan dalam kerangka corak kepentingan dan ideologi mereka masing-masing. Dalam konteks ini, sejarah tafsir mencatat adanya perkembangan berbagai corak tafsir. Misalnya muncul Tafsir al-Razi dengan corak filsafatnya yang ditulis oleh Fakhr al-Razi, al-Kasyafdengan corak teologi mu'tazilahnya yang ditulis oleh al-Zamakhsyari, Tafsir al-Manar dengan corak sosiologinya yang ditulis oleh Muhammad Rasyid Ridha, dan seterusnya sesuai latar belakang keilmuan mufassirnya (Komara, 2019).

Secara garis besar, corak tafsir yang digunakan dalam penafsiran DI-Fillah atas ayat-ayat kerasulan adalah corak tafsir politik. Untuk membuktikan corak tafsir politik yang dominan dalam penafsiran DIFillah atas ayat-ayat kerasulan dapat dilihat dari pandangan mereka, bahwa kerasulan belum berakhir. Dengan pimpinan DI-Fillah mengklaim sebagai rasul terakhir yang dijanjikan turun diakhir zaman, mereka hendak mencapai kekuasaan dengan jalan konversi dari RI ke NII, merubah nama, bentuk dan sifat dari nasional menjadi Negara Islam Madani atau Negara Islam Indonesia, dengan tidak merubah struktur pemerintah RI seperti tidak berubahnya struktur pemerintah Yatsrib setelah menjadi Negara Madinah. Karena menurut mereka, hanya seorang rasul yang akan mampu menyelesaikan kebobrokan Negara Indonesia saat ini.

Satu hal yang esensial dalam pandangan mereka, bahwa al-Qur'an diinterpretasi guna terwujudnya Negara Madani, Negara Islam Indonesia. Interpretasi yang dibentuk oleh pengalaman Nabi saw. dalam mendirikan Negara Islam di Madinah. Nabi saw. menafsirkan dan mengamalkan al-Qur'an hingga terwujud Negara Islam. Maka dari itu, menurut mereka, ciri penafsiran yang benar terhadap al-Qur'an yaitu penafsirnya akan menguasai 2/3 dunia, seperti pada masa Nabi Muhammad saw (Rahayu, 2019).

Penafsiran DI-Fillah selalu melibatkan penerapan (aplikasi) sebuah teks ke dalam realita yang dialami penafsir (pembaca). Dan semangat teks sesungguhnya bagi mereka adalah pembebasan umat Islam dari belenggu dan tekanan baik dari luar maupun dari dalam. Ayat-ayat al-Qur'an oleh mereka direpresentasikan pada kepentingan dan ideologi yang sedang diperjuangkan. Penafsiran dilakukan sebagai usaha DI-Fillah untuk mencapai kekuasaan, mempertahankannya dan mensukseskan cita-cita dalam mendirikan Negara Islam Indonesia dengan jalan konversi dan rasul sebagai pemimpinnya.

\section{Pengaruh Penafsiran Darul Islam Fillah Terhadap Keberagamaan}

\section{Syahadat}

Pada pertengahan tahun 2007, warga NII/DI-Fillah melakukan bai'at dengan mengakui Sensen Komara sebagai Rasulullah dengan mengucap syahadat "Asyhadu an laa ilaha illallah wa asyhadu anna Drs. Sensen Komara bin Bakar Misbah bin KH. Abdul Mughni Rasulullah". Perubahan syahadat dengan menggunakan nama Sensen ini juga dilakukan dalam adzan dan tasyahud ketika shalat, hanya saja dilakukannya hanya satu kali, dengan alasan para pengikutnya khawatir kesulitan (balelol) mengucapkannya dalam shalat (Komara, 2019).

Dalam pandangan mereka, tasyahud itu terjadi apabila datangnya seorang rasul. Jika terbukti di dalam al-Qur'an dan sunnah akan datangnya utusan Allah maka ada pula tasyahud, jadi tasyahud adalah bersifat sekunder dan yang menjadi primernya adalah kerasulan, karena kalau tidak ada lagi rasul maka tidak ada syahadat. 


\section{Hijrah}

Peristiwa hijrah seyogiannya dipahami oleh setiap Muslim yang ingin meneladani Rasul dalam mengemban amanah Khaliqnya. Kata hijrah, berarti perpindahan (to desert) secara geografis_juga missionaries_dari Mekah ke Yatsrib (Madinah) pada tahun 622 M. Dalam Islam, hijrah merupakan tonggak sejarah penting peran profetik Nabi Muhammad Saw. pada masa jahiliyyah, dari kekerasan spiritual ke kedamaian, dari ketidakadilan dan penindasan ke pembebasan (taharrur), dan dari dogma ke peradaban.

Dari sinilah hijrah menempati arti penting dalam perjuangan Islam pada masa Nabi Muhammad Saw. sehingga Umar bin Khattab kemudian menetapkannya secara resmi sebagai kalender tahun baru Hijriyyah yang diawali pada bulan Muharram, tepatnya bulan Juni $622 \mathrm{M}$.

Sementara, peristiwa hijrah Nabi Muhammad Saw. dari Mekah ke Yatsrib_dengan merubah nama dari Yatsrib menjadi Madinah_oleh DI-Fillah dijadikan sebagai dasar konversi dari RI menjadi NII, dengan merubah nama, sifat, dan bentuk. Mereka konseptualisasikan peristiwa hijrah dalam satu rumusan Darul Islam (Negara Islam).

Konversi yang dilakukan oleh DI-Fillah ini didasarkan pada QS. al-Isra [17]: 80

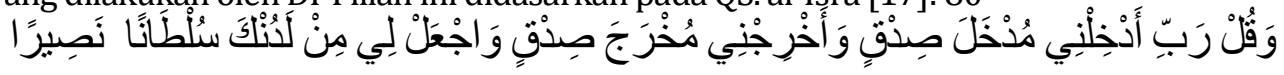

"Dan katakanlah: "Ya Tuhan-ku, masukkanlah aku secara masuk yang benar dan keluarkanlah (pula) aku secara keluar yang benar dan berikanlah kepadaku dari sisi Engkau kekuasaan yang menolong".

Menurut DI-Fillah, yang dimaksud dengan Mudkhal itu adalah Yastrib dan Mukhraj adalah Mekah. Dan yang dimaksud dengan Sulthanan-nashira adalah Madinah. Untuk menyelamatkan Negeri Arab adalah terwujudnya Sulthanan-nashira atau Negara penolong yaitu terwujudnya Negara Baru Madinah. Dari penafsiran ini jelas mereka membedakan antara Yatsrib sebelum dan sesudah berubah nama menjadi Madinah, dan dijadikannya sebagai legitimasi pendirian Negara Islam.

Penafsiran ini merupakan pengembangan dari apa yang diungkapkan Kartosoewiryo dalam bukunya Sikap Hidjrah yang disahkan oleh kongres PSII pada tahun 1936 di Jakarta, bahwa yang dimaksud dengan Mekah dan Madinah, Habsyi dan 'Ic itu letaknya di Indonesia, di kampung dan negeri kita sendiri, di tempat kelahiran dan tanah tumpah darah kita sendiri. Ringkasnya, Mekkah-Indonesia, HabsyiIndonesia, Madinah-Indonesia, 'Ic-Indonesia (S.M. Kartosoewiryo, 1939). Kemudian, dimaknai konsep hijrah ini oleh DI-Fillah dengan:

a. Mekah-Indonesia (Muhajir) adalah tempat lahirnya hukum Islam yaitu Negara Islam Indonesia (NII), yang diproklamasikan 7 Agustus 1949. Jadi Mekah di Indonesia itu adalah NII

b. Yatsrib-Indonesia (Anshar) adalah RI yang diproklamasikan 17 Agustus 1945. Jadi Yatsrib di Indonesia adalah RI, yaitu tempat hijrahnya muhajirin NII setelah dikeluarkannya perintah Kartosoewiryo 24 April 1962 dan 6 Juni 1962

c. Madinah-Indonesia adalah RI yang telah berubah nama, bentuk dan sifat dari nasional menjadi Negara Islam Madani atau Negara Islam Indonesia dengan tidak merubah struktur pemerintah RI seperti tidak berubahnya struktur pemerintah Yatsrib setelah menjadi Negara Madinah. Nama "Negara-Madinah-Indonesia" sulit dibedakan dengan istilah "NII" seperti sulit dibedakannya nama "Madinah" dengan "Yastrib". Orang zaman Nabi menyebut nama Madinah itu untuk nama Yastrib begitu juga ketika menyebut nama Yastrib itu untuk Madinah karena Yastrib dan Madinah tidak dapat dipisahkan karena kedua-duannya menunjuk satu negeri dan berada dalam negeri yang sama. 
Untuk mewujudkan konversi, pemimpin DI-Fillah Sensen Komara atas nama SM. Kartosuwiryo telah mengangkat 12 Imam, yang berasal dari Yatsrib Indonesia (RI) yang akan bertanggung jawab terhadap umatnya masing-masing dalam pembentukan Negara Madinah Indonesia atau NII. 12 Imam itu adalah:

1. Imam Besar K.H. Samanhudi

2. Imam Besar K.H. Oemar Said Cokroaminoto

3. Imam Besar Dr. Ir. Soekarno

4. Imam Besar Amir Sarifudin

5. Imam Besar S.M. Kartosuwiryo

6. Imam Besar Jendral Besar H.M. Suharto

7. Imam Besar Prof. Dr. Ir. B.J. Habibie

8. Imam Besar K.H. Abdurrahman Wahid

9. Imam Besar Hj. Megawati Sukarno Putri

10. Imam Besar Kolonel Jaja Sujadi Rahmat

11. Imam Besar Kapten Bakar Misbah

12. Imam Besar Jenderal H. Susilo Bambang Yudhoyono

Pengangkatan 12 Imam ini dengan menggunakan konsep 12 mata air, tujuannya adalah untuk bersama-sama menyelamatkan Negara Indonesia dari bahaya kehancurannya. "Menyelamatkan" bersama-sama dengan 12 Imam itu menurut mereka, seperti halnya Nabi Muhammad saw. memindahkan Hajar Aswad yang pada waktu itu runtuh karena musibah banjir, dimana masing-masing pemimpin mengambil bagian untuk memindahkan hajar aswad ke tempatnya, yaitu Ka'bah.

Selain itu, DI-Fillah berpandangan, di dalam tarikh, Nabi Muhammad saw. hijrah dari Mekah ke Madinah. Dan umat di akhir zaman akan melakukan hijrah secara terbalik yaitu dari Madinah ke Mekah. Pemahaman seperti ini mengakibatkan belum berlakunya hukum pada fase Mekah, termasuk shalat. Karena menurut mereka, apa yang terjadi di Mekah harus terjadi di Mekah dan apa yang terjadi di Madinah harus berlaku pula di Madinah.

\section{Kiblat}

Pengaruh lainnya dari penafsiran DI-Fillah dalam hal beragama yaitu perubahan arah shalat dengan menghadap ke Timur sebagai kiblat. Mereka beragumetasi bahwa di dalam sunnah Nabi Muhammad saw. telah melaksanakan shalat dengan menghadap ke ka'bah melalui dua arah (dua kiblat), yaitu arah Selatan dan arah Utara. Perubahan kiblat ini tidak ada penjelasan mengenai alasan dan sebabsebab terjadinya perubahan kiblat, yang mana menurut mereka_dengan mengutip pendapat atThabari_sebagaimana dahulu di dalam perubahan kiblat Allah dan Rasul-Nya tidak memberikan penjelasan, sehingga banyak orang menduga bahwa perubahan kiblat itu keinginan Nabi saw. sendiri yang kemudian dibenarkan Allah.

Ketika terjadi perubahan kiblat, timbullah keraguan orang-orang musyrik, munafik, dan ahli kitab, mereka bertanya: "apa yang memalingkan mereka (Nabi dan umatnya), yakni apa yang membuat mereka kadang-kadang berkiblat ke Baitul Maqdis (Utara) dan kadang-kadang ke ka'bah (Selatan)?. Itulah pertanyaan dari mereka yang meragukan atau menyalahkan dan menyesatkan terhadap perubahan kiblat. Pertanyaan itu memunculkan jawaban yang beraneka ragam dari kalangan orang-orang musyrik dan munafik, mereka menduga bahwa Nabi Muhammad saw. berkiblat ke Jerussalem karena Maqdis berada di Utara. Apapun jawaban dan dugaan mereka, Allah menyebutnya dengan kalimat sufaha (bodoh). Sebagaimana dalam firman Allah swt. QS. al-Baqarah [2]: 142-143 


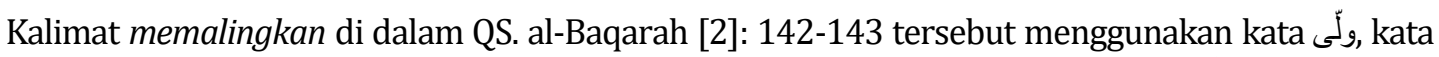

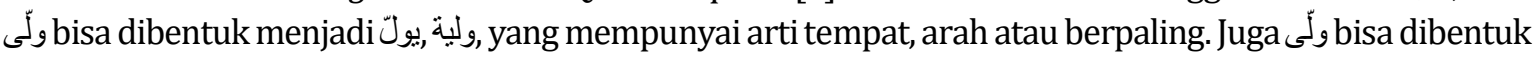

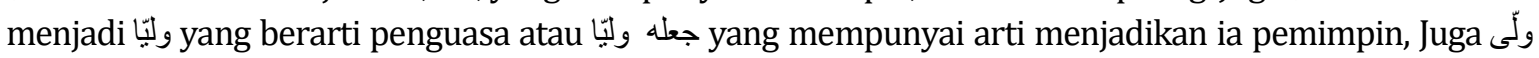
berarti ما ولّهم ولّما dalam ayat di atas menurut mereka, berarti berpaling atau memindahkan arah dari arah semula (tempat semula) ke arah yang lain atau berpaling dari arah yang dekat ke arah yang jauh dengan tujuan, berpindah arah ini, karena Allah akan menjadikan Muhammad saw. seorang pemimpin dunia. Kata ولّى bukan berarti pindah dari ka'bah menjadi Baitul Maqdis, tetapi ka'bah tetap menjadi kiblat shalat hanya berpindah arah melalui arah Utara ('aradha 'an-menjauhi) menuju Ka'bah. Karena berbalik dari Selatan ke Utara, maka posisi Nabi membelakangi Ka'bah. Maka,

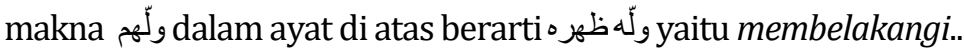

\section{SIMPULAN}

Berdasarkan pembahasan tersebut di atas, maka dapat disimpulkan bahwa DI-Fillah mengklaim sebagai juru bicara teks yang paling otoritatif dan mumpuni dalam melakukan penafsiran terhadap alQur'an, mereka menilai penafsiran yang ada hingga dewasa ini bersifat nisbi dan tidak pernah selesai. Penafsiran terhadap al-Qur'an hanya akan selesai dan benar apabila penafsiran tersebut bersumber dari Allah swt. lewat wahyu, sumber yang sama dengan al-Qur'an. Ciri penafsiran yang benar terhadap alQur'an menurut mereka, yaitu penafsirnya akan menguasai 2/3 dunia dengan terbentuknya Negara Islam seperti yang terjadi pada masa Nabi Muhammad saw. di Madinah.

Dalam pada itu, DI-Fillah mengesampingkan peranan akal dalam menafsirkan al-Qur'an, dan hal ini bertentangan dengan ajaran al-Qur'an itu sendiri, di mana al-Qur'an memerintahkan untuk mentadaburi dan memahami makna ayat-ayatnya, berpikir dan menghayati pesan-pesannya, serta menarik pelajaran darinya. Sebaliknya, al-Qur'an mengancam terhadap orang yang mengabaikannya, serta mengecam orang yang hanya mengikuti suatu pendapat tanpa suatu dasar, mereka itu dinilai oleh al-Qur'an sebagai orang yang telah terkunci hatinya.

Metode tafsir yang digunakan DI-Fillah atas ayat-ayat kerasulan adalah metode maudhu'i, dengan menentukan tema kerasulan, kemudian memilih ayat-ayat yang menurut mereka menunjukkan adanya rasul setelah kerasulan Nabi Muhammad saw. Dari sekian banyaknya ayat-ayat mengenai kerasulan dalam al-Qur'an, DI-Fillah memilih setidaknya enam ayat mengenai kerasulan yang dijadikan argumentasi akan adanya rasul setelah kerasulan Nabi Muhammad saw., yaitu: QS. Ad-Dukhan [44]: 5, QS. Al-Mu'minun [23]: 43-44, QS. An-Nisa [4]: 41, QS. Yunus [10]: 47, QS. al-Qashash [28]: 59, QS. al-Isra [17]: 15. Dalam melakukan penafsiran dengan menggunakan tafsir maudhu'i, DI-Fillah tidak memperhatikan sabab annuzul masing-masing ayat, dan tidak melakukan pengkajian keseluruhan ayat dan penjelasan dari berbagai aspek secara utuh, sehingga timbul perbedaan dan pemaksaan, dan akhirnya diperoleh pandangan al-Qur'an tidak sempurna mengenai kerasulan.

Sumber atau pendekatan tafsir yang digunakan DI-Fillah dalam penafsiran mereka terhadap ayatayat kerasulan terkadang dengan menggunakan perananan akal, namun lebih dominan masuk pada pendekatan bathiniyah (kebatinan), di mana DI-Fillah mengakui keabsahan wahyu sebagai kalam Ilahi, dan al-Qur'an bersumber dari-Nya, namun untuk mencapai pada pemahaman teks yang benar, penafsiran harus juga bersumber dari-Nya. DI-Fillah mengganggap hal itu sebagai satu-satunya jalan untuk mencapai kebenaran dalam penafsiran. Akan tetapi, seringkali penafsiran mereka bertentangan dengan dalil syar'i dan juga dalil 'aqli.

Corak tafsir yang digunakan dalam penafsiran DI-Fillah atas ayat-ayat kerasulan adalah corak tafsir politik. Mereka berpandangan, bahwa yang akan mampu melepaskan negara Indonesia dari beban dan 
belenggu, serta dari adzab Allah hanyalah seorang rasul dengan jalan konversi dari RI ke NII, dengan merubah nama, bentuk dan sifat dari nasional menjadi Negara Islam Madani atau Negara Islam Indonesia, dengan tidak merubah struktur pemerintah RI seperti tidak berubahnya struktur pemerintah Yatsrib setelah diganti nama oleh Nabi Muhammad saw. menjadi Madinah, Negara Islam Madani.

Jelas bahwa DI-Fillah mempunyai kepentingan yang lebih dahulu ada dimana mereka ingin mencari peneguhan dari al-Qur'an, serta mempunyai pra-konsepsi dimana mereka ingin mencari penguat bagi pandangan mereka dari al-Qur'an. Hingga mereka mencondongkan istilah-istilah dan ayat-ayat alQur'an untuk melayani kepentingan serta menguatkan pemikiran yang sedang mereka perjuangkan yaitu pendirian Negara Islam Indonesia.

Oleh karena itu, umat Islam perlu kiranya meningkatkan kualitas ilmu tentang studi al-Qur'an dan tafsir khususnya, guna menjaga al-Qur'an dari pemahaman-pemahaman yang keliru dan menyimpang, serta memelihara agama Allah swt. dari reduksi pemahaman orang-orang yang berlebihan dan melampaui batas (ifrath), pemalsuan ahli kebathilan, dan penafsiran orang-orang yang tidak memiliki metodologi yang benar dalam memahami sebuah teori yang diinginkan dan ditunjukan oleh al-Qur'an. Wallahu a'lam.

\section{DAFTAR PUSTAKA}

abidin, Z., \& Khairudin, F. (2017). Penafsiran Ayat-Ayat Amanah Dalam Al-Qur'an. Syahadah, 5(2). Al-Khalidi, S. 'Abdul F. (2008). At-Tafsir Al-Maudhu'i Baina An-Nadhariyyah Wa At-Tathbiq. Oman: Dar An-Nafais.

Arsip Darul Islam Fillah. (1975). Agama: Pokok-Pokok Pemikiran Hidup Beragama, Pandangan Hidup Islam. Garut.

Baidan, N., \& Aziz, E. (2016). Metodologi Khusus Penelitian Tafsir. Yogyakarta: Pustaka Pelajar.

Komara, S. (2019). Hasil Wawancara. Garut.

Muslim, M. (1997). Mabahis Fi At-Tafsir Al-Maudhu'i. Dimsyaq: Dar Al-Qalam.

Rahayu, D. (2019). Hasil Wawancara. Garut.

Ruhana, A. S. (2011). Gerakan Nii Di Babakan Cipari Dan Empat Pilar Kebangsaan. Dialog, 34(1), 119-140.

S.M. Kartosoewiryo. (1939). Sikap Hijrah Psii. Garut: Malangbong/Batavia-C.

Setiawan, W. (2010). Argumentasia Mengapa Aku Percaya? Garut.

Shihab, M. Q. (2013). Sejarah Ulumul Qur'an. Jakarta: Pustaka Firdaus. Jakarta: Pustaka Firdaus.

Sugiyono. (2013). Metode Penelitian Pendidikan Pendekatan Kauntitatif, Kualitatif Dan R\&D. Bandung: Alfabeta.

Zada, K. (2017). Politik Perlawanan Muslim Cipari (Garut) Terhadap Radikalisme Gerakan Darul Islam. Istiqro', 15(2). 